International Journal of Osteoarchaeology

Int. J. Osteoarchaeol. (2008)

Published online in Wiley InterScience

(www.interscience.wiley.com) DOI: 10.1002/oa.991

\title{
Trends in Adult Stature of Peoples who Inhabited the Modern Portuguese Territory from the Mesolithic to the Late $20^{\text {th }}$ Century
}

\author{
H. F. V. CARDOSO ${ }^{a *}$ AND J. E. A. GOMES ${ }^{b}$ \\ a Departamento de Antropologia, Universidade de Coimbra, Rua do Arco da Traição, \\ 3000-056 Coimbra, Portugal \\ b Departamento de Antropologia, Universidade Nova de Lisboa, Avenida de Berna 26-C, \\ 1069-061 Lisboa, Portugal
}

\begin{abstract}
This study documents long-term changes in stature from the Mesolithic to the late $20^{\text {th }}$ century in the territory of modern Portugal. Data utilised originated from published sources and from a sample of the Lisbon identified skeletal collection, where long bone lengths were collected. Mean long bone lengths were obtained from 20 population samples and compiled into nine periods. Pooled long bone lengths for each period were then converted to stature estimates. Results show three major trends: (1) a slow increase in stature from prehistory to the Middle Ages; (2) a negative trend from the Middle Ages to the late $19^{\text {th }}$ century; and (3) a very rapid increase in mean stature during the second half of the $20^{\text {th }}$ century. The political and territorial stability of the Kingdom of Portugal may have contributed to the greater heights of the medieval Portuguese, compared with the Roman and Modern periods. The negative secular trend was rooted in poor and unsanitary living conditions and the spread of infectious disease, brought about by increased population growth and urbanisation. Although the end of the Middle Ages coincided with the age of discoveries, the population may not have benefited from the overall prosperity of this period. The $20^{\text {th }}$ century witnessed minor and slow changes in the health status of the Portuguese, but it was not until major improvements in social and economic conditions that were initiated in the 1960s, and further progress in the 1970s, that the Portuguese grew taller than ever before. Since the Middle Ages other European countries have experienced similar oscillations, but showed an earlier recovery in stature after the industrial period. Copyright (c) 2008 John Wiley \& Sons, Ltd.
\end{abstract}

Key words: stature; health; living conditions; secular trend; Portugal

\section{Introduction}

Explaining spatial and temporal variations in human health and population well-being have become major concerns for anthropologists, social historians and economists. One of the major aims has been to document variations in the

* Correspondence to: Departamento de Antropologia, Rua do Arco da Traição, Universidade de Coimbra, 3000-056 Coimbra, Portugal. e-mail hcardoso@antrop.uc.pt standard of living across time, and traditionally this has been achieved by analysing trends in life expectancy and per capita GDP. However, the analysis of changes in living stature can supplement data series on traditional measures, but particularly can greatly extend their chronological reach. The use of stature data to infer variations in the standard of living relies on the assumption that human growth is responsive to changes in the environment. In other words, this kind of study relies on the notion that 'a child's 
growth rate reflects, better than any other single index, his state of health and nutrition [...]. Similarly, the average values of children's heights [...] reflect accurately the state of a nation's public health and the average nutritional status of its citizens' (Eveleth \& Tanner, 1976: 1). Because growth is, by definition, a period of biological immaturity, it is more sensitive to the environment and thus considered a good indicator of its quality. Thus, the rate of growth of the individuals of any population and their final attained height are very sensitive indicators of the living standards of any society as reflected by sanitary conditions, nutritional quality, amount of energy expenditure and overall health (Susanne, 1984; Bogin, 1999; Fogel, 1986; Schell, 1989; Tanner, 1982).

In much the same way as children's growth and adult stature are considered good indices of the nutritional and health state of a population, secular trends in growth and stature are also regarded as good indices of temporal changes in nutritional and health conditions. This phenomenon, known as secular trend, concerns physical maturation of children occurring more rapidly, and children and adults becoming larger than children and adults of several generations ago (Susanne, 1984; Tanner, 1989; Malina, 1990; Bogin, 1999). The factors that influence the secular trend are related to the material conditions of life which act upon human growth over long spans of time, namely changes towards better nutrition, in particular more protein and caloric intake during infancy, lessening of disease, as well as better hygiene and delivery of medical care (Tanner, 1989, 1992; Bogin, 1999). For example, during the $19^{\text {th }}$ and $20^{\text {th }}$ centuries a remarkable increase in mean height and earlier maturation has been observed in almost all European countries (Bodzsar \& Susanne, 1998; Susanne et al., 2001; Cole, 2003). This has occurred as a consequence of social and economic transformations brought about by industrialisation and increased urbanisation, but especially by social, economic and political changes that took place after the Second World War. Similarly, a decline in overall living conditions can also result in a persistent decrease in stature, in which case the trend is inverted and a negative secular change occurs (Tobias, 1988; Bogin, 1999).

Copyright (C) 2008 John Wiley \& Sons, Ltd.
The main source of evidence for the study of changes in human adult stature is records of military recruitment. Conscript data have been used for some time to illustrate long-lasting trends in physical growth and, consequently, the population's standard of living (e.g. Komlos, 1998, 2003; Federico, 2003; López-Alonso \& Condey, 2003; Haines, 2004). However, when dealing with prehistoric or historical populations for which there are no documentary records of living adult stature, researchers have turned to skeletal remains from archaeological sites to reconstruct past stature. Osteometric variables such as long bone length provide simple cumulative measures of physical growth in skeletal samples, and since there is a high correlation between stature and long bone length $(\sim 0.8)$ (e.g. Pearson, 1899; Trotter \& Gleser, 1952), measurements of long bones can be used as proxies for statural growth. As a result, long bone lengths have been extensively used in the study of temporal variations in stature of prehistoric and historical populations (e.g. Laluenza-Fox, 1998; Formicola \& Giannecchini, 1999; Bogin \& Keep, 1999; Steckel et al., 2002; Schweich \& Knüsel, 2003; Steckel, 2004; Gerhards, 2005; Koepke \& Baten, 2005; Maat, 2005).

Because there are several techniques with which to estimate stature from long bone lengths, one crucial aspect in examining long tendencies in stature estimated from skeletal remains is to ensure comparability of estimates over time. This can be accomplished either by comparing absolute long bone lengths, or by comparing estimates of stature obtained from the same method and the same bone length. Given that the various reference samples differ in relative proportions of their limbs and in the proportions of limbs to stature, the use of different formulae will not provide consistent results, as estimates from different formulae will differ (Waldron, 1998). For example, stature obtained from the regression formulae of Trotter \& Gleser (1952) can consistently overestimate stature calculated from Pearson's (1899) method by as much as 4 to $5 \mathrm{~cm}$ or more (Cardoso, 2000).

In Portugal, secular trends in adult stature and child growth have been documented since the late $19^{\text {th }}$ century from historical anthropometric data (Sobral, 1990; Caninas, 2002; Padez, 2003; 
Cardoso, 2008). Over the years, archaeological excavations have unearthed thousands of human remains from several prehistoric and historical periods, which have been studied by Portuguese physical anthropologists. Analysis of these remains has provided a glimpse into the lives of past peoples in Portugal since prehistory, namely in the reconstruction of their likely living stature. However, this source of information has remained scattered over various publications, which have been produced over the years, and was never collated and compared to provide an extended chronological view. The purpose of this study is to document temporal variations in the stature of peoples who inhabited the modern Portuguese territory since the Mesolithic, and tentatively infer the overall social and economic conditions of living that have influenced the nutritional and health status of these populations over time. Collection of data was targeted at prehistoric and historical archaeological samples which have been studied for other purposes and for which data on long bone lengths were made available in published sources.

\section{Materials and methods}

Data utilised in this study originated from published materials and from long bone lengths collected from a sample of the Lisbon identified skeletal collection. Published data were selected only when either raw long bone lengths were provided, or when long bone lengths could be directly obtained by 'reversing' stature estimates, as long as these were calculated from only one long bone measurement. 'Reversing' stature estimates means that the estimated stature value was replaced in the stature formulae and then solved for long bone length. This 'reversing' was preferable to using the original stature estimate because this offered the opportunity to obtain long bone lengths for all periods and then estimate stature using just one method, rather than compiling stature estimates obtained from diverse techniques. This meant that published materials which did not identify the stature estimation method, or did not describe or were unclear on how it was calculated (for example, whether estimates from different bones were pooled), were eliminated from the study.

The long bone measurements selected were femur maximum length and humerus maximum length, because these were the only measurements incorporated into the stature estimation method (Mendonça, 2000) chosen for this study. This method was devised for estimating the stature of modern Portuguese in forensic casework, and its choice was based on the fact that stature estimates obtained from it in all prehistoric and historical samples would be directly comparable to modern stature and over time. Most of the published materials included these two measurements, except two studies (Gameiro, 1998, 2003). In these two, only oblique or bicondylar length of the femur was provided. Given that these were the only two Roman period studies available, bicondylar length was converted into maximum length. This was achieved by selecting 100 males and 100 females from the Lisbon identified skeletal collection and developing sex-specific regression equations to estimate maximum length from bicondylar length (males: max. length $=1.017^{*}$ bicond. length 5.219， $\mathrm{R}=0.998, \quad \mathrm{R}^{2}=0.995$; females: $\max$. length $=1.006^{*}$ bicond. length $+0.381, \mathrm{R}=0.996$, $\mathrm{R}^{2}=0.992$ ), which was achieved with a very high degree of reliability.

The descriptive statistics for the raw data used in this study, by time period and sample, can be found in Table 1, with the respective references. Studies vary greatly in sample size, from samples of only one usable individual to population studies of up to 200 individuals. The fragmentary nature of the materials reported in several publications and the insufficiency of raw data were limiting factors in obtaining larger sample sizes. The standard deviation of long bone length could not be obtained from all samples. Some publications provided individual data, which were used to calculate the standard deviation, whereas others only included summary data, such as mean long bone lengths (or mean stature estimates) for the male and female samples. Whenever standard deviations were available, these were used to calculate standard errors for population estimates, while assessing differences between periods. All studies are published as scholarly theses or as papers in scientific DOI: $10.1002 /$ oa 
H. F. V. Cardoso and J. E. A. Gomes

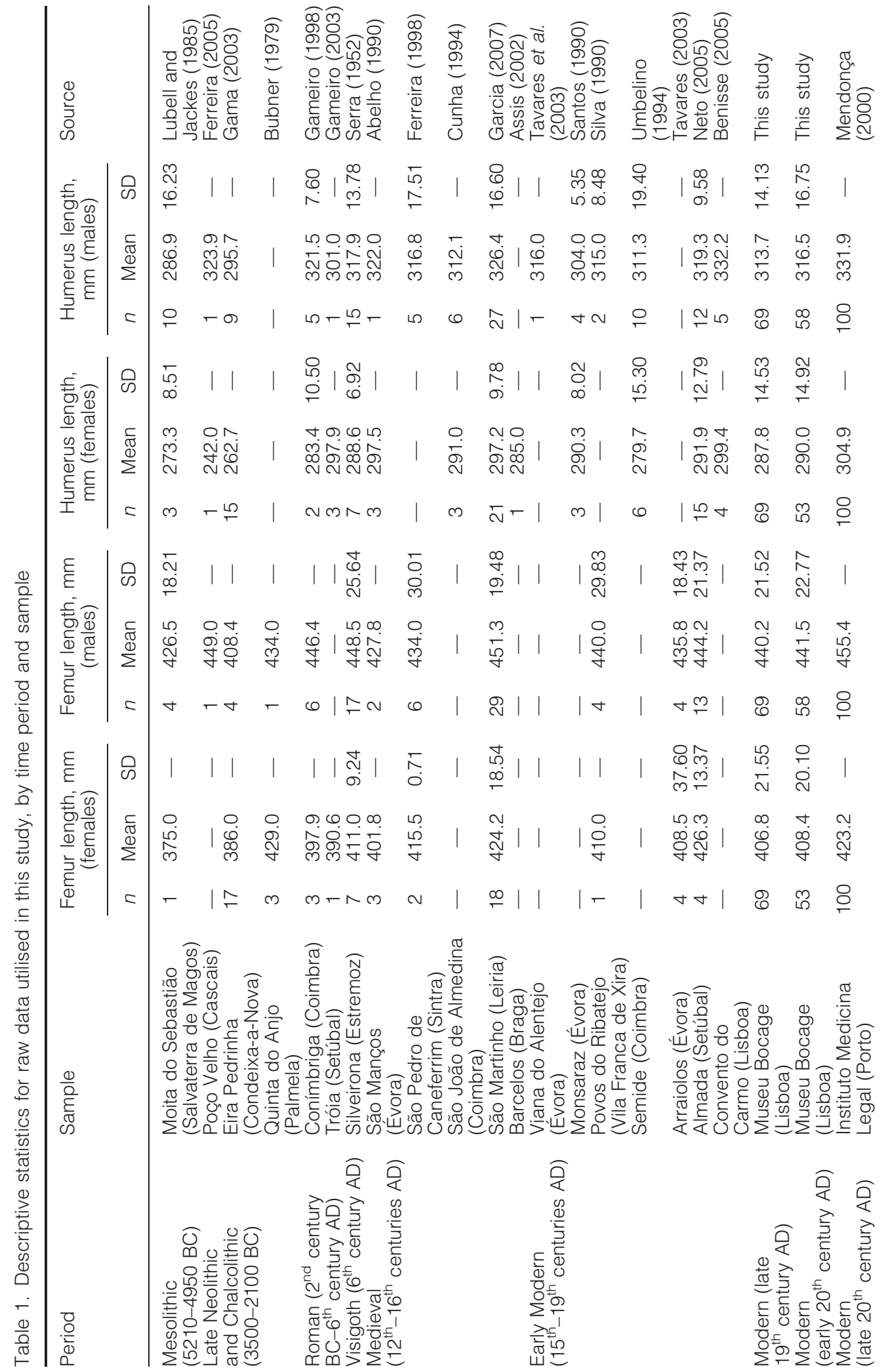

Copyright (C) 2008 John Wiley \& Sons, Ltd.

Int. J. Osteoarchaeol. (2008)

DOI: 10.1002/oa 
periodicals and, therefore, rigour in age and sex determination methods employed has been scrutinised in a scientific manner. Whenever significant doubts were raised regarding the accuracy with which age and sex were determined in a certain sample, it was eliminated from the analysis. Age was not considered an important factor in this study, but special attention was paid to the collection of adult data only. Most authors were not concerned with the social status of the individuals in their samples, and no publications provided sufficient information for a social categorisation. However, the nature of the sites indicates a majority of studies representative of the overall population (e.g. prehistoric collective burials, historical public cemeteries, churchyards). Therefore, none of the samples seems to represent a particularly privileged or underprivileged social group.

After obtaining mean femur and humerus maximum lengths for the male and female sample of each publication, data were compiled into nine different periods or epochs: Mesolithic, Late Neolithic/Chalcolithic, Roman, Visigoth, Medieval, Early Modern, Late $19^{\text {th }}$ century (Modern), Early $20^{\text {th }}$ century (Modern) and Late $20^{\text {th }}$ century (Modern) (see Table 1). Although all periods may not be totally homogeneous in their composition, both spatially and temporally, this organisation of data was done out of necessity and convenience, according to the accepted Portuguese prehistoric and historical periodisation. Taken together, the samples cover a time span of approximately seven millennia. The various epochs are sometimes separated by considerable periods of time, which indicates missing information. This was the case for the Muslim occupation between the Visigoth and Medieval periods, for the Bronze and Iron Ages between the Chalcolithic and the Roman period, the early and middle Neolithic, and the Palaeolithic. Absence of data in the Muslim and Neolithic periods is related to the scarcity of published materials or poor preservation of samples, whereas in the Bronze and Iron Ages it is mostly related to burial practices, which included cremation as the most common funerary ritual. During Roman times cremation was also a very common practice, and hence the small sample for this period. With respect to burial practices, it is important to note that samples from most sites comprise individual graves, whereas from the late Neolithic/Chalcolithic they originate from collective burials. All samples derive from skeletal remains, retrieved mostly from urban sites in Central and Coastal Portugal.

Data from the Modern period were obtained from two sources: the Lisbon collection (late $19^{\text {th }}$ and early $20^{\text {th }}$ centuries) and a forensic sample (late $20^{\text {th }}$ century; Mendonça, 2000). The availability of recent materials provided greater detail into stature variations over the last 150 years, compared with earlier studies. The Lisbon collection is a documented series of approximately 700 skeletons curated at the Bocage Museum (National Museum of Natural History) in Lisbon, Portugal, which derives from modern cemetery sources (Cardoso, 2006). The individuals in the collection are all of Portuguese origin and roughly represent a birth range from 1880 to 1960 . This relatively wide time interval allowed two periods to be sampled from the collection: one of individuals born before 1900 (Modern - late $19^{\text {th }}$ century AD) and the other of individuals born after 1900 (Modern - early $20^{\text {th }}$ century AD). Although this was a somewhat arbitrary separation, it took advantage of the full range of birth years in the collection and also coincided roughly with major social, economic and political transitions that occurred in Portugal, with the decline of the monarchy around 1890 and the establishment of a republic in 1910. Femur and humerus maximum length was collected on a sample of 138 individuals (69 females and 69 males) born before 1900 and on a sample of 111 individuals (53 females and 58 males) born after 1900 .

Late $20^{\text {th }}$ century data derive from Mendonça (2000) and comprise stature measurements of 100 male and 100 female cadavers collected over a period of a few years prior to 1998 in the National Institute of Legal Medicine in Porto, Portugal. These individuals are all Portuguese nationals, born during the late $20^{\text {th }}$ century in the northern regions of the country. Mendonça's forensic sample and the two other modern samples are meant to represent different cohorts within a given time interval. Because Mendonça's sample represents several cohorts over a roughly 50-year period, it combines stature from a period of very intense positive secular trend (Padez, 2003).

Int. J. Osteoarchaeol. (2008) DOI: $10.1002 /$ oa 
Table 2. Mean stature estimates calculated from femur maximum length

\begin{tabular}{|c|c|c|c|c|c|c|}
\hline \multirow[t]{2}{*}{ Period } & \multicolumn{2}{|c|}{ Females } & \multicolumn{2}{|c|}{ Males } & \multicolumn{2}{|c|}{ Sexes pooled } \\
\hline & $n$ & Mean & $n$ & Mean & $n$ & Mean \\
\hline Mesolithic (5210-4950 BC) & 1 & 146.3 & 4 & 160.2 & 5 & 153.3 \\
\hline Late Neolithic and Chalcolithic (3500-2100 BC) & 20 & 150.5 & 6 & 158.3 & 26 & 154.4 \\
\hline Roman $\left(2^{\text {nd }}\right.$ century BC- $6^{\text {th }}$ century AD) & 4 & 151.5 & 6 & 165.5 & 10 & 158.5 \\
\hline Visigoth ( $6^{\text {th }}$ century AD) & 7 & 154.8 & 17 & 166.1 & 24 & 160.4 \\
\hline Medieval $\left(12^{\text {th }}-16^{\text {th }}\right.$ centuries AD) & 23 & 157.1 & 37 & 165.7 & 60 & 161.4 \\
\hline Early Modern $\left(15^{\text {th }}-19^{\text {th }}\right.$ centuries AD) & 9 & 156.1 & 21 & 164.3 & 30 & 160.2 \\
\hline Modern (late $19^{\text {th }}$ century AD) & 69 & 153.8 & 69 & 163.9 & 138 & 158.8 \\
\hline Modern (early $20^{\text {th }}$ century AD) & 53 & 154.2 & 58 & 164.2 & 111 & 159.2 \\
\hline Modern (late $20^{\text {th }}$ century AD) & 100 & 157.7 & 100 & 167.9 & 200 & 162.8 \\
\hline
\end{tabular}

After compiling samples, data within each epoch were combined to calculate mean long bone length for males and females of that epoch. When there was more than one sample in each period, mean long bone length was calculated as a weighted mean, by combining average stature of all samples in that period, using the sample size of each sample as the weighting factor; otherwise the mean long bone length of the only sample was used. Next, stature estimates from each period and sex group were obtained from weighted femur and humerus maximum length means. Since stature estimates obtained from these two long bones can provide different results, stature estimates based on femur and humerus were not pooled and are presented separately. For the latest period (late $20^{\text {th }}$ century) the data refer to actual stature measurements rather than estimates. Sex determination methodologies varied from study to study, and in order to avoid observer and/or technique biases, a sex-pooled estimate of stature was obtained from each period. The estimates of stature were then plotted against the time line.

\section{Results}

Mean stature estimates for each period are shown in Tables 2 and 3. Data in each table are broken down by sex, and also includes sample sizes and sex-pooled estimates for each period. In Table 2, statures were estimated from femur maximum length, and in Table 3 from humerus maximum length. Although sample sizes are somewhat low in some periods, they are largely comparable to those of other similar studies (e.g. de Beer, 2004; Gerhards, 2005; Maat, 2005). Stature estimated

Table 3. Mean stature estimates calculated from humerus maximum length

\begin{tabular}{|c|c|c|c|c|c|c|}
\hline \multirow[t]{2}{*}{ Period } & \multicolumn{2}{|c|}{ Females } & \multicolumn{2}{|c|}{ Males } & \multicolumn{2}{|c|}{ Sexes pooled } \\
\hline & $n$ & Mean & $n$ & Mean & $n$ & Mean \\
\hline Mesolithic (5210-4950 BC) & 3 & 148.0 & 10 & 153.2 & 13 & 150.6 \\
\hline Late Neolithic and Chalcolithic (3500-2100 BC) & 16 & 144.4 & 10 & 157.0 & 26 & 150.7 \\
\hline Roman $\left(2^{\text {nd }}\right.$ century BC- $6^{\text {th }}$ century AD) & 5 & 153.8 & 6 & 163.4 & 11 & 158.6 \\
\hline Visigoth ( $6^{\text {th }}$ century AD) & 7 & 152.7 & 15 & 163.3 & 22 & 158.0 \\
\hline Medieval $\left(12^{\text {th }}-16^{\text {th }}\right.$ centuries AD) & 28 & 155.0 & 39 & 165.0 & 67 & 160.0 \\
\hline Early Modern $\left(15^{\text {th }}-19^{\text {th }}\right.$ centuries AD) & 28 & 153.2 & 34 & 162.9 & 62 & 158.1 \\
\hline Modern (late $19^{\text {th }}$ century AD) & 69 & 152.5 & 69 & 162.0 & 138 & 157.2 \\
\hline Modern (early $20^{\text {th }}$ century AD) & 53 & 153.1 & 58 & 162.9 & 111 & 158.0 \\
\hline Modern (late $20^{\text {th }}$ century AD) & 100 & 157.7 & 100 & 167.9 & 200 & 162.8 \\
\hline
\end{tabular}


Adult Stature from the Mesolitbic to Modern Portugal

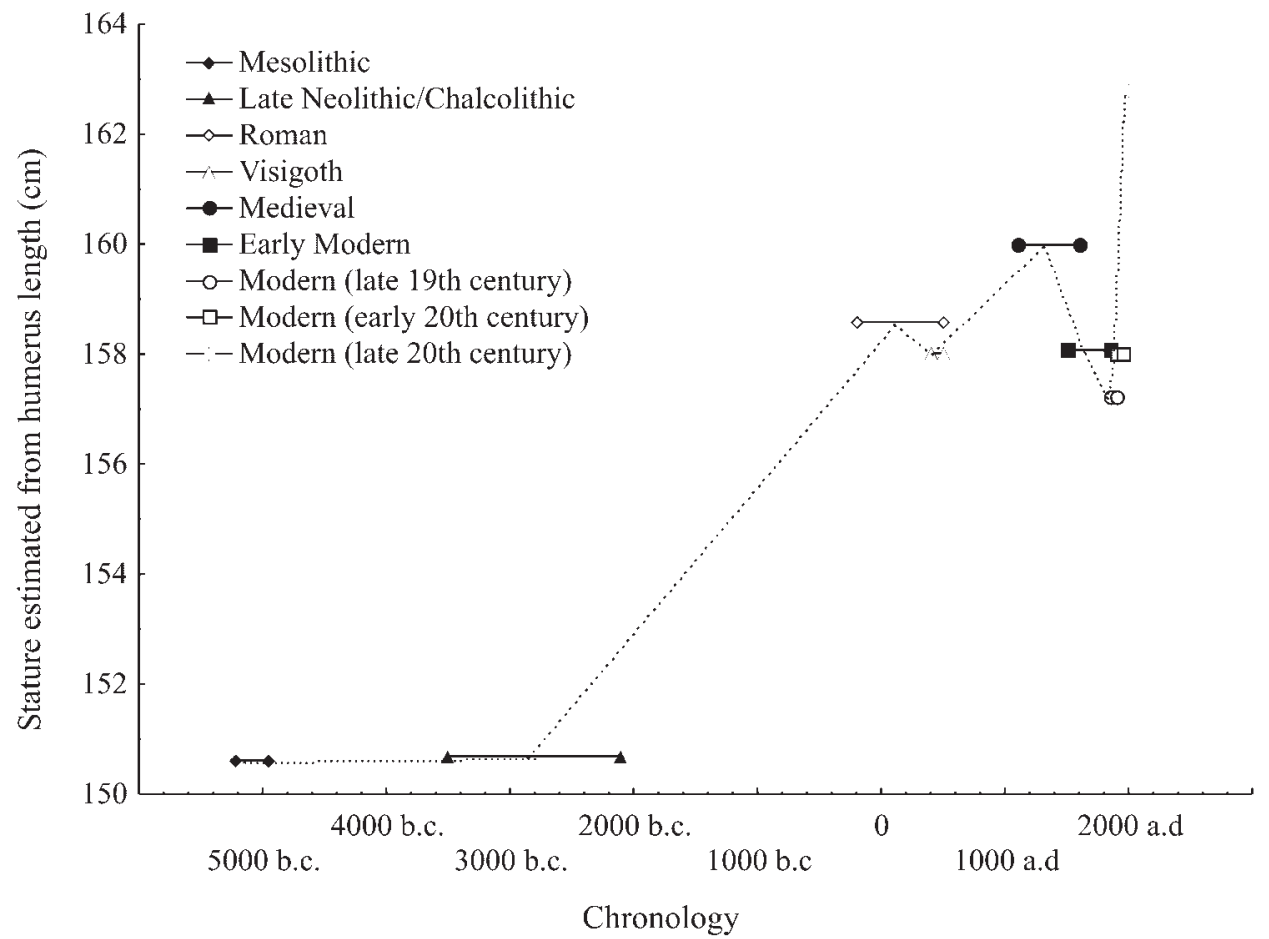

Figure 1. Evolution of mean stature estimated from femur length when the sexes are pooled. The dotted line connects mean stature values at the centre of each time interval.

from femur length is almost always greater than stature estimated from humerus length, but the overall variation across time does not change significantly between both sets of estimates. The only exception is the transition between the Roman and Medieval periods, which also shows differences when the sexes are compared across time. This can be seen more clearly in Figures 1 and 2, where sex-pooled stature estimates have been plotted against the time line. In Figure 1, stature increased from the Roman, to the Visigoth and then to the Medieval period, whereas in Figure 2 stature decreased from the Roman to the Visigoth period, after which it increased. This is certainly related to the small samples of the Roman and Visigoth periods, and consequently their potentially more erratic estimates, but also because they were not based entirely on the same individuals. However, stature in the Visigoth period is only smaller than stature in the Roman period for the female sample, and when it is estimated from humerus length (Tables 2 and 3 ).
Despite the difficulties with sample sizes and with the inability to obtain a measure of dispersion, such as the standard deviation, and differences in estimates between long bones and between the sexes, the data show a rather consistent pattern across the time period under examination. This pattern can be summarised as follows: (1) no significant changes in mean stature between the Mesolithic and Late Neolithic/ Chalcolithic samples; (2) an apparent secular change towards increased stature from the Chalcolithic to the Roman period, but which does not account for missing data from preRoman peoples; (3) no significant change in stature from the Roman to the Visigoth period; (4) an increase in stature towards the Medieval period which, at this point, seems to include the tallest individuals - this transition also does not account for missing data from the Muslim

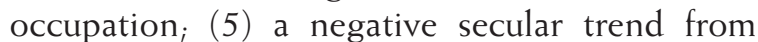
the Medieval to the Early Modern period and then $_{i}$ (6) an apparent decrease towards the late $19^{\text {th }}$ century; (7) a slight, albeit insignificant, 


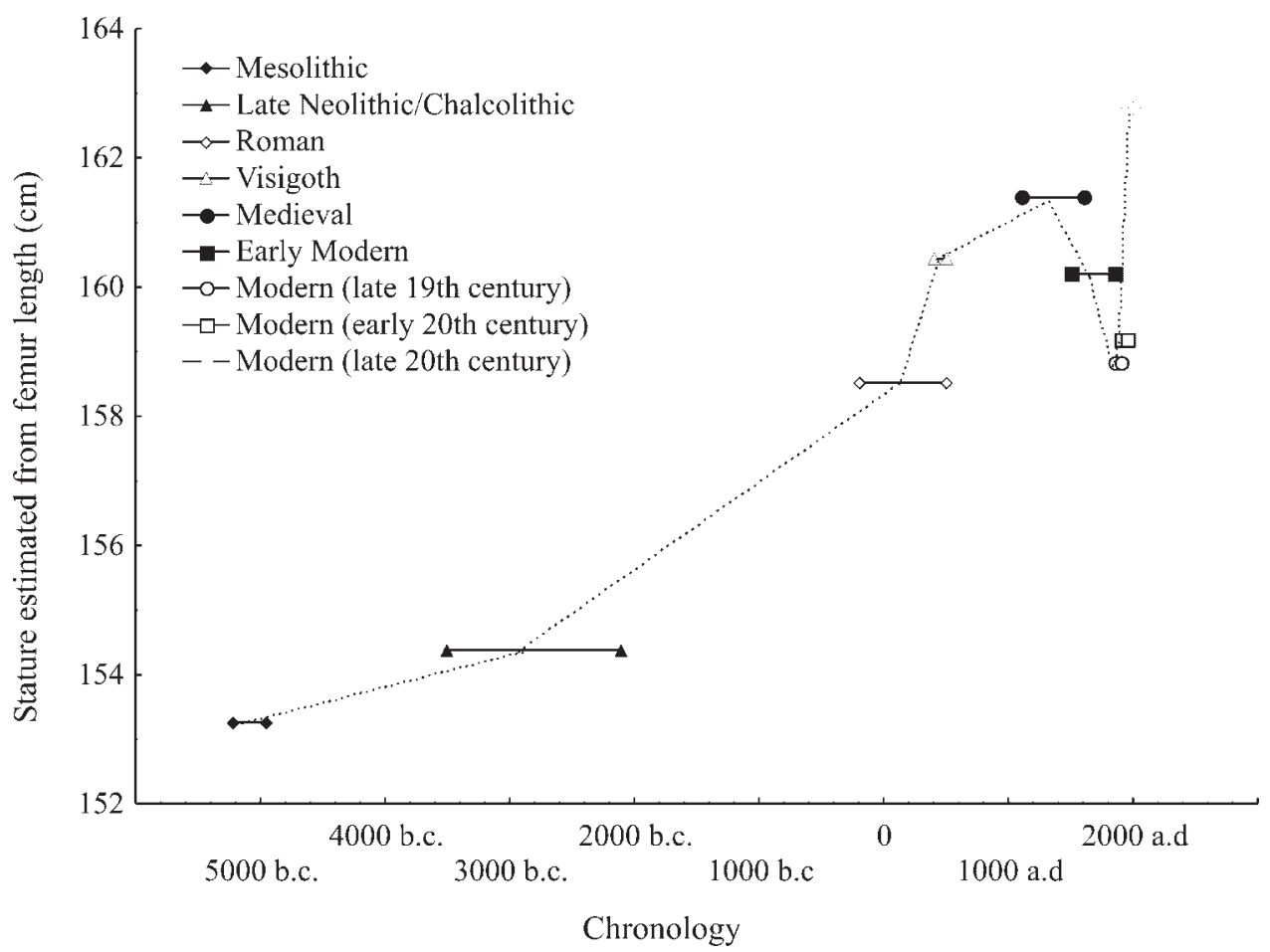

Figure 2. Evolution of mean stature estimated from humerus length when the sexes are pooled. The dotted line connects mean stature values at the centre of each time interval.

recovery in the early $20^{\text {th }}$ century; and (8) an accelerated increase in stature during the last 40 years or so. Minimum mean sex-pooled stature is 153.3 and $150.6 \mathrm{~cm}$, when obtained from Mesolithic femur and humerus length, respectively. Maximum mean sex-pooled stature was obtained for the modern Portuguese at $162.8 \mathrm{~cm}$. Stature seems to have increased by approximately $7.0-9.4 \mathrm{~cm}$ between the Mesolithic/Neolithic and the Middle Ages, to decrease by around $2.6-2.8 \mathrm{~cm}$ until the late $19^{\text {th }}$ century, after which a mean increase of $4.0-5.6 \mathrm{~cm}$ took place.

\section{Discussion}

Although the sample sizes for prehistoric and older historical periods may be considered small, and data from important periods are missing, this study was the first in which temporal variations in stature were examined over such a long period of time in Portugal. Accordingly, the results of this study offer a tentative first analysis of the changes

Copyright (C) 2008 John Wiley \& Sons, Ltd. in stature since the Mesolithic in the modern Portuguese territory. Besides samples not always being adequate in terms of size, they may also not represent the full variety of populations living in the modern Portuguese territory at each epoch. Some geographical areas may be more represented than others, and the different populations of each period may show considerable variation in mean stature, particularly if large spans of time are being examined. Given the natural limitations of these sorts of studies, we are left to assume that these variations in stature reflect real population phenomena over time. The fact that the skeletal remains represent a very limited geographical variation and were retrieved from sites which probably represent the majority of the population at each locality (such as prehistoric collective burials, historic public cemeteries, churchyards and the like) and not a particular social group, gives some support to this assumption. Of course, the fact that raw data could not be obtained from all samples was also problematical, given that no statistical analysis

Int. J. Osteoarchaeol. (2008) DOI: $10.1002 /$ oa 
could be performed to test the significance of differences in mean stature between periods.

Another potential difficulty with this study is that it must be assumed that late $20^{\text {th }}$ century statures (Mendonça, 2000) are directly comparable to stature estimates in all prehistoric and historical periods, because stature has been estimated from regression formulae developed on the late $20^{\text {th }}$ century sample. Although the late $20^{\text {th }}$ century Portuguese may have differed from earlier populations in the relative proportions of the trunk and leg to body height, this approach is the best approximation we can aspire to with respect to reconstruction of stature from skeletal samples. Unless a measure of skeletal height, leg length and trunk height can be obtained consistently, which is particularly difficult to achieve with skeletal remains, stature estimates can only be comparable across populations or epochs if calculated using the same methodology or if only absolute lengths are used, as we have done in this study.

Data examined here suggest a first positive secular trend in stature from the Mesolithic to the Middle Ages. The Mesolithic-Neolithic transition has been associated with an overall decrease in health, namely malnutrition and increased infection, due to the lifestyle and subsistence changes that occurred from foraging to farming economies (Cohen \& Armelagos, 1984). Data in this study, however, do not show such a reduction in living conditions. The inability to detect significant stature changes between the Mesolithic and the Late Neolithic/ Chalcolithic may result from small and unrepresentative Mesolithic samples, or in turn, given the missing data from the early and middle Neolithic, it may suggest that the initial decrease in stature from the Mesolithic to the early Neolithic was not sampled and that there was a recovery towards the end of the Neolithic and Chalcolithic. For example, Gerhards (2005) found that Mesolithic people from Latvia were as tall as Late Neolithic people, but early and middle Neolithic populations were significantly shorter. An alternative explanation could be that the Mesolithic peoples were not significantly taller than the Neolithic populations because the negative health impacts of a sedentary and agricultural life were already established in the Mesolithic. This explanation is consistent with skeletal and isotopic evidence presented by Jackes et al. (1997a,b), Lubell et al. (1994) and Cunha et al. (2004), which suggests that the Portuguese Mesolithic was not necessarily replaced by a miserable and unhealthy Neolithic. These authors also suggest that the MesolithicNeolithic transition in Portugal shows a shift in diet and subsistence, but that it was not sudden, but rather gradual and continuous. These arguments, however, are not totally incompatible with models of population replacement (Zilhão, 1998).

The changes in mean stature between the Late Neolithic/Chalcolithic and the Roman period may not be interpreted as a continuous increase, because the pre-Roman peoples were not sampled and Roman sample sizes are small. Nevertheless, the tendency is suggestive of an increase in stature compared with early pre-historic populations. The Roman occupation meant the enforcement of a modus vivendi, which included a novel model of urbanised society, with cities at its centre. These urban centres were well planned and organised, built with great hygienic concerns, and were connected by an extensive network of roads and water routes, which provided continuous exchange of goods and commodities (Fabião, 1992). Although Roman societal organisation and hygiene may have contributed to an improvement in living standards, and thus to an increase in stature, increasing urban population densities and social inequalities may have also had a detrimental impact on large sectors of the society, particularly the lower classes who did not enjoy the commodities provided by the Roman modus vivendi (Koepke, 2002). Although the increase in stature from the Chalcolithic to the Roman period may be indicative of a positive impact of Roman societal organisation on health, and consequently on stature, the greater heights of medieval populations suggest worse living conditions in the Roman world.

Although the collapse of the Roman Empire implied a change in societal organisation, through the disappearance of Roman institutions and the introduction of new customs brought by the Germanic invasions, namely the ruralisation and feudal organisation of society (Mattoso, DOI: $10.1002 /$ oa 
1992), the transition between the Roman and Visigoth periods may not have resulted in any significant changes in mean stature. The collapse of Roman rule did not result from war, generalised epidemics or crop failures, and the occupation of the territory by the Visigoths may have only altered the centres of power and administration, with no major negative consequences for the living standards and health of the local populations. Unfortunately, the analysis of the transition to the Middle Ages lacks data from the Muslim occupations, which occurred between the Visigoth kingdom and the foundation of Portugal.

With the foundation of the kingdom of Portugal $\left(12^{\text {th }}\right.$ century), the overall living conditions of the population most likely improved. The political stability allowed for major social and economic developments, namely technological agricultural innovations which effectively increased agricultural production and allowed wider distribution of goods (Marques, 1980; Mattoso, 1993), which in turn allowed for an improvement in diets (Fernandes, 1993). Although the Portuguese early Middle Ages witnessed an increase in population, this process did not mean an increase in population density, particularly in urban centres, because it coincided with the southern expansion of the Portuguese territory, conquered from the Muslims (Mattoso, 1993). Despite a few epidemic outbreaks and brief periods of starvation, the Portuguese Middle Ages were a period of relative economic prosperity (Marques, 1980). The relative political stability and an efficient and relatively isolated economy, allied to a low density of population, may have contributed to overall good living conditions, which provided the environment for the Portuguese to grow taller than ever before. The Middle Ages seem to represent the endpoint of approximately 6000 years of positive trend in stature, and it was not until five centuries later that they would become yet taller. A similar study carried out by Laluenza-Fox (1998), using several skeletal samples from the Iberian peninsula, including Portugal, has found the same overall trend of increasing stature until the Middle Ages, although it does not include data from the Early Modern Ages.

Copyright (C) 2008 John Wiley \& Sons, Ltd.
From the Middle Ages until the late 19th century, mean stature seems to have declined. This decrease can be correlated with the increase in population density and urbanisation which occurred in Portugal after the Middle Ages. During the Early Modern Ages the population grew steadily, as well as the number and size of urban centres (Rodrigues, 1993; Serrão, 1993). In addition, poor hygiene was generalised, medical care was scarce, and welfare was practically nonexistent. Assistance was only provided during periods of epidemic crisis, and then priority was always given to members of the upper classes (Rodrigues, 1993; Braga, 2001). Unhygienic and overcrowded conditions in most of the cities and towns, together with a generalised lack of assistance for the sick, resulted in frequent epidemics and poor health for the population. Poor nutrition during the Portuguese Early Modern Ages, compared with the Middle Ages, has been associated with deficient labour for cultivating the fields, competition from cheaper foreign products, diversion of resources for the Portuguese overseas expansion, and lack of investment in technology by the great landowners who still exploited peasant labour (Magalhães, 1993). These poor living conditions during the early Modern age in Europe, which are also described by de Beer (2004), Steckel (2004) and Maat (2005), resulted in a decrease in stature from the Middle Ages to the early $19^{\text {th }}$ century. For example, Steckel (2004), using medieval and modern samples from northern Europe, found that the most prosperous period was the Middle Ages.

This reduction in overall health status during the Early Modern period seems to contradict the prosperity associated with the Portuguese age of discoveries and colonial expansion during the $15^{\text {th }}$ and $16^{\text {th }}$ centuries and later. Yet, economic development may not automatically have translated into good health status. This period was one of concentration of capital, and probably mostly benefited the wealthy and people from the main centres of commerce, such as the capital city. The economy was also unstable and based on Portuguese colonial trade, which did not greatly benefit home markets (Magalhães, 1993). Problems brought about by increased urbanisation may also have been

Int. J. Osteoarchaeol. (2008) DOI: $10.1002 /$ oa 
reinforced and later intensified, such as the spread of disease brought by the voyages that built and maintained the colonial empires (Steckel, 2004). In addition, Portugal gradually saw its wealth decreasing after the $16^{\text {th }}$ century. The country was under the rule of Spanish kings from 1580 to 1640, and Portuguese colonies became the subject of attacks by Spain's opponents, namely Holland, England and France. With a smaller population and unable to defend its overseas colonies and trading posts effectively, the Portuguese empire began its long and gradual decline. The country was further weakened by the destruction of much of its capital city in a 1755 earthquake, by the Napoleonic invasions, and later by the loss, in 1822, of its largest and wealthiest colony, Brazil (Fernandes et al., 2003).

The decline of the country as a world political power, its fragile agricultural system, incomplete and incipient industrialisation and weak capitalist system, further depressed the living conditions of the population during the $19^{\text {th }}$ century. Contrary to what was the case in several European countries, where there was a generalised decrease in mean stature between the late $18^{\text {th }}$ and early $19^{\text {th }}$ century during industrialisation (Komlos, 1998; A'Hearn, 2003; Federico, 2003; Haines, 2004; Maat, 2005), stature in Portugal was probably still decreasing by the late $19^{\text {th }}$ century. Although there are no Portuguese health or social development statistical indicators available for the $19^{\text {th }}$ century to support and illustrate this assertion, the social and economic delay relative to several other European countries is well documented for the $20^{\text {th }}$ century (e.g. Tortella, 1994; Schmidt et al., 1995). However, it is likely that, because the late $19^{\text {th }}$ century sample derives from the largest Portuguese city, Lisbon, where living conditions may have been more depressed than in other cities, the decrease in stature may be slightly amplified. Lisbon was an important industrialised area during the late $19^{\text {th }}$ century and reflected the increasingly difficult conditions of the working classes: greater income inequality, rapid population growth and urbanisation, and extremely unhygienic conditions of overcrowding and lack of sanitation, which helped to spread all sorts of communicable diseases (Crespo, 1990). For example, all kinds of household waste were habitually thrown into the streets of Lisbon by the late $19^{\text {th }}$ century. Lack of medical assistance, contaminated water sources and intentionally compromised foods were also responsible for considerable misery and spread of disease in most Portuguese cities and towns (Crespo, 1990).

After a relatively long period of negative secular trend, there may have been a slight recovery in mean stature from the late 19th century to the early 20th century. However, it was not until the 1960s and 1970s that the Portuguese experienced a significant secular increase in stature (Padez, 2003). In this respect, the evolution of stature between the late $19^{\text {th }}$ century and the late $20^{\text {th }}$ century is consistent with the secular trend documented for Portugal from conscript data (Padez, 2003). Portugal emerged into the $20^{\text {th }}$ century as a declining world political power, with a late and incomplete industrialisation, a heavily primary sector based on poor and rudimentary agriculture and insufficient penetration of market mechanisms. In 1910 Portugal was established as a republican state, and then in 1926 it gave rise to the longest standing dictatorship in Europe (Baiôa et al., 2003). It was not until 1974 that a military coup overthrew the dictatorship and set the basis for a democratic system, which accomplished major improvements in economic and social welfare. Therefore, during most of the $20^{\text {th }}$ century, Portugal experienced only very slow change, but in a few decades, particularly since the country's union with the EFTA (European Free Trade Association) in 1960, the country accomplished what other nations took considerably more time to achieve. Portugal experienced rapid growth and change from a mostly agrarian society to one strongly oriented towards the service sector. It was not until relatively late that the Portuguese benefited from the invention of food refrigeration, better and cheaper foods, improvements in housing, public health and sanitation associated with running water and sewer systems, as well as improvements in welfare and medical care.

Since the Middle Ages, the Portuguese seem to have experienced oscillations in mean stature similar to those of other European peoples (e.g. Komlos, 1998; A'Hearn, 2003; Federico, 2003; de Beer, 2004; Haines, 2004; Steckel, 2004; Maat, 2005). Overall, after a long period of decrease in 
the centuries immediately following the Middle Ages, the negative trend in mean stature was reversed after the industrial period. The main difference seems to be one of delay in recovery of stature, which took place in other central and northern European countries after industrialisation in the late $19^{\text {th }}$ century. The initial turning point in stature trend for the Portuguese seems to have occurred only in the early $20^{\text {th }}$ century, but very faintly. A long period of relatively slow changes was followed by a sharp acceleration in stature in the last 40 years. Although differences in mean stature between periods could not be statistically tested, major patterns seem valid and consistent with historical and/or archaeological evidence.

\section{Conclusion}

The analysis of approximately 7000 years of variation in mean stature of peoples who inhabited the modern Portuguese territory has shown that the most important shifts have been the slow increase in stature from prehistory to the Middle Ages, the negative trend thereafter, and the remarkable recovery and rapid increase over the last decades. This pattern provides an insight into changes in living conditions and overall health of the population which is not dependent on historical accounts or documentary sources of demography and income or wealth. Although stature data examined in this study seem to conform to general historical knowledge from standard sources, particularly since the Middle Ages, it challenges the conventional notion that medieval peoples lived in a time of misery and plague, the so-called 'Dark Ages', and also defies the Portuguese colonial era as one of great prosperity.

\section{Acknowledgements}

The authors would like to thank the reviewers for their helpful comments, Dr Susana Garcia for providing data ahead of print, Dr Ana Maria Silva for suggestions, and Dr Cláudia Sousa for support during several stages of the project. Prof. Cristina Padez sparked the idea for this study.

\section{References}

Abelho M. 1990. Estudo antropológico dos enterramentos de S. Manços, (Évora). Antropologia Portuguesa 8: 69-100.

A'Hearn B. 2003. Anthropometric evidence on living standards in Northern Italy, 1730-1860. Journal of Economic History 63: 351-381. DOI: 10.1017/ S0022050703001827

Assis S. 2002. Vilas de Frades - reminiscências do passado: estudo paleodemográfico e paleopatológico de uma amostra antropológica proveniente do Convento de Vilar de Frades. Honours thesis, University of Coimbra, Portugal.

Baiôa M, Fernandes PJ, Meneses FR. 2003. The political history of twentieth-century Portugal. e-Journal of Portuguese History 1.2 (Winter 2003). Available at: http://www.brown.edu/Departments/ Portuguese_Brazilian_Studies/ejph/html/issue2/pdf/ baioa.pdf [accessed 9 June 2007].

Benisse V. 2005. Retrato da Lisboa Moderna: Estudo paleobiológico de uma amostra da população exumada do convento do Carmo (Séc. XVI-XVIII). Master's thesis, University of Coimbra, Portugal.

Bodzsar E, Susanne C. 1998. Secular Growth Change in Europe. Eòtvòs Lorand University: Budapest.

Bogin B. 1999. Patterns of Human Growth. Cambridge University Press: Cambridge.

Bogin B, Keep R. 1999. Eight thousand years of economic and political history in Latin America revealed by anthropometry. Annals of Human Biology 26: 333-351. DOI: 10.1080/030144699282651

Braga IMRMD. 2001. Assistência, saúde pública e prática médica em Portugal. Séculos XV-XIX. Universitária Editora: Lisboa.

Bubner T. 1979. Restos humanos dos hipogeus do Casal do Pardo (Palmela). Ethnos 8: 87-105.

Caninas M. 2002. Tendência secular: Morfologia e prestação motora numa prova de handgrip. Master's thesis, Universidade Técnica de Lisboa, Cruz Quebrada.

Cardoso HFV. 2000. Dimorfismo sexual na estatura, dimensões e proporçôes dos ossos longos dos membros. Master's thesis, University of Coimbra, Portugal.

Cardoso HFV. 2006. Brief communication: The collection of identified human skeletons housed at the Bocage Museum (National Museum of Natural History), Lisbon, Portugal. American Journal of Physical Antbropology 129: 173-176. DOI: 10. 1002/ajpa.20228

Cardoso HFV. 2008. Secular changes in body height and weight of Portuguese boys over one century. American Journal of Human Biology 20: 270-277. DOI: 10.1002/ajhb. 20710

Cohen MN, Armelagos GJ. 1984. Paleopathology at the Origins of Agriculture. Academic Press: Orlando. 
Cole TJ. 2003. The secular trend in human physical growth: a biological view. Economics and Human Biology 1: 161-168. DOI: 10.1016/S1570-677X(02)00033-3 Crespo J. 1990. A bistória do corpo. Difel: Lisboa.

Cunha E. 1994. Paleobiologia das populações medievais portuguesas. Os casos de Fão e S. João de Almedina. $\mathrm{PhD}$ thesis, University of Coimbra, Portugal.

Cunha E, Umbelino C, Silva AM, Cardoso F. 2004. What can pathology say about the Mesolithic and Late Neolithic/Chalcolithic communities? The Portuguese case. In Paleopathology at the Origins of Agriculture Revisited, Cohen MN (ed.). Florida University Press, Clearwater. Available at: http://faculty. plattsburgh.edu/mark.Cohen/Cunha\%20et\%20al. htm [accessed 20 October 2007].

de Beer H. 2004. Observations on the history of Dutch physical stature from the late-Middle Ages to the present. Economics and Human Biology 2: 45-55. DOI: 10.1016/j.ehb.2003.11.001

Eveleth PB, Tanner JM. 1976. Worldwide Wide Variation in Human Growth. Cambridge University Press: Cambridge.

Fabião C. 1992. A romanização do actual território Português. In História de Portugal, antes de Portugal, volume 1, Mattoso J (ed.). Circulo de Leitores: Lisboa; 203-293.

Federico G. 2003. Heights, calories and welfare: a new perspective on Italian industrialization, 1854-1913. Economics and Human Biology 1: 289-308. DOI: 10.1016/S1570-677X(03)00071-6

Fernandes H. 1993. Vida Rural e Alimentação. In História de Portugal, Portugal Medieval, volume 3, Medina J (ed.). Ediclube: Lisboa; 315-317.

Fernandes PJ, Meneses FR, Baiôa M. 2003. The political history of nineteenth-century Portugal. e-Journal of Portuguese History 1.1 (Summer 2003). Available at: http://www.brown.edu/Departments/ Portuguese_Brazilian_Studies/ejph/html/issue1/pdf/ fernandes.pdf [accessed 9 June 2007].

Ferreira N. 1998. Paleobiologia de um grupo populacional medieval de S. Pedro de Caneferrim. Honours thesis, University of Coimbra, Portugal.

Ferreira N. 2005. Paleobiologia de grupos populacionais do Neolítico Final/Calcolítico do Poço Velho (Cascais). Trabalhos de Arqueologia 40. Available at: http://www.ipa.min-cultura.pt/pubs/TA/folder/40/ [accessed 8 May 2007].

Fogel RW. 1986. Physical growth as a measure of the economic well-being of populations: the eighteenth and nineteenth centuries. In Human Growtb: A Comprebensive Treatise, Falkner F, Tanner JM (eds). Plenum Press: New York; 263-281.

Formicola V, Giannecchini M. 1999. Evolutionary trends of stature in upper paleolithic and mesolithic
Europe. Journal of Human Evolution 36: 319-333. DOI: 10.1006/jhev. 1998.0270

Gama R. 2003. Ressuscitar Eira Perimba: Neolítico, calcolítico. Uma nova abordagem antropológica. Honours thesis, University of Coimbra, Portugal.

Gameiro A. 1998. A necrópole de Conímbriga: Estudo antropológico de alguns dos seus restos bumanos. Honours thesis, University of Coimbra, Portugal.

Gameiro A. 2003. Tróia Romana - Paleobiologia de uma população Romana da necrópole de Tróia. Master's thesis, University of Coimbra, Portugal.

Garcia MSJ. 2007. Maleitas do corpo em tempos medievais. Indicadores paleodemográficos, de stresse e paleopatológicos numa série osteológica urbana de Leiria. PhD thesis, University of Coimbra, Portugal.

Gerhards G. 2005. Secular variations in the body stature of the inhabitants of Latvia (7th millennium BC - 20th c. AD). Acta Medica Lituanica 12: 33-39.

Haines M. 2004. Growing incomes, shrinking people can economic development be hazardous to your health? Social Science History 28: 249-270. DOI: 10.1215/01455532-28-2-249

Jackes M, Lubell D, Meiklejohn C. 1997a. On the physical anthropological aspects of the MesolithicNeolithic transition in the Iberian Peninsula. Current Antbropology 38: 839-846.

Jackes M, Lubell D, Meiklejohn C. 1997b. Healthy but mortal: human biology and the first farmers of western Europe. Antiquity 71: 639-658.

Koepke N. 2002. Anthropometric decline of the Roman Empire? Regional differences and temporal development of the quality of nutrition in the Roman provinces of Germania and Raetia from the first century to the fourth century AD. Proceedings of the XIII Economic History Congress. International Economic History Association: Buenos Aires. Available at: http://eh.net/XIIICongress/Papers/Koepke. pdf [accessed 2 July 2007].

Koepke N, Baten J. 2005. The biological standard of living in Europe during the last two millenia. European Review of Economic History 9: 61-95. DOI: $10.1017 / \mathrm{S} 1361491604001388$

Komlos J. 1998. Shrinking in a growing economy? The mystery of physical stature during the Industrial Revolution. Journal of Economic History 58: 779802 .

Komlos J. 2003. An anthropometric history of earlymodern France. European Review of Economic History 7: 159-189. DOI: $10.1017 / S 1361491603000066$

Laluenza-Fox C. 1998. Stature and sexual dimorphism in ancient Iberian populations. Homo 49: 260-272.

Lopez-Alonso M, Condey R. 2003. The ups and downs of Mexican economic growth: the biological standard of living and inequality, 1870-1950. 


\section{H. F. V. Cardoso and J. E. A. Gomes}

Economics and Human Biology 1: 169-186. DOI: 10.1016/S1570-677X(03)00039-X

Lubell D, Jackes M. 1985. Mesolithic-Neolithic continuity: evidence from chronology and human biology. In Proceedings of the 1 a reunião do quaternário Ibérico, volume 2, Grupo de Trabalho Português do Quaternário (ed.). Grupo de Trabalho Português do Quaternário: Lisboa; 113-133.

Lubell D, Jackes M, Schwarcz H, Knyf M, Meiklejohn C. 1994. The Mesolithic-Neolithic transition in Portugal: isotopic and dental evidence of diet. Journal of Archaeological Science 21: 201-216.

Maat G. 2005. Two millennia of male stature development and population health and wealth in the Low Countries. International Journal of Osteoarchaeology 15: 276-290. DOI: 10.1002/oa.785

Magalhães J. 1993. As estruturas de produção agrícola e pastoral. In História de Portugal, No Alvorecer da Modernidade, volume 3, Mattoso J (ed.). Circulo de Leitores: Lisboa; 243-282.

Malina RM. 1990. Research on secular trends in auxology. Antbropologischer Anzeiger 48: 209-227.

Marques A. 1980. Ensaios da bistória medieval Portuguesa. Editorial Veja: Lisboa.

Mattoso J. 1992. A época Sueva e Visigótica. In História de Portugal, Antes de Portugal, volume 1, Mattoso J (ed.). Circulo de Leitores: Lisboa; 305-356.

Mattoso J. 1993. 1096-1325: A formação da nacionalidade no espaço Ibérico. In História de Portugal, A. Monarquia Feudal (1096-1480), volume 2, Mattoso J (ed.). Circulo de Leitores: Lisboa; 11-312.

Mendonça M. 2000. Estimation of height from the length of long bones in a Portuguese adult population. American Journal of Pbysical Antbropology 112 : 39-48.

Neto F. 2005. Estudo paleobiológico da necrópole da igreja da misericórdia de Almada. Master's thesis, University of Coimbra, Portugal.

Padez C. 2003. Secular trend in stature in the Portuguese population(1904-2000). Annals of Human Biology 30: 262-278. DOI: 10.1080/0301446031 000064530.

Pearson K. 1899. Mathematical contributions to the theory of evolution. On the reconstruction of the stature of prehistoric races. Pbilosopbical Transactions of the Royal Society of London (Series A) 192: 169-244.

Rodrigues T. 1993. As estruturas populacionais. In História de Portugal, No Alvorecer da Modernidade, volume 3, Mattoso J (ed.). Circulo de Leitores: Lisboa; 197-242.

Santos A. 1990. Contribuição para o estudo antropológico dos restos humanos exumados na igreja paroquial de Santiago Maior (Monsaraz, Évora). Antropologia Portuguesa 8: 39-58.
Schell LM. 1989. Community health assessment through physical anthropology: Auxological epidemiology. Human Organization 45: 321-327.

Schmidt IM, Jørgensen MH, Michaelsen KF. 1995. Height of conscripts in Europe: is postneonatal mortality a predictor? Annals of Human Biology 22: 57-67. DOI: 10.1080/03014469500003702

Schweich M, Knüsel C. 2003. Bio-cultural effects in medieval populations. Economics and Human Biology 1 : 367-377. DOI: 10.1016/j.ehb.2003.09.002

Serra J. 1952. Características da população da época Visigótica de Silveirona (Estremoz) I - Estatura e robustez dos ossos longos. Contribuições para o Estudo da Antropologia Portuguesa 5: 201-233.

Serrão J. 1993. O Quadro Humano. In História de Portugal, Antigo Regime, volume 4, Mattoso J (ed.). Circulo de Leitores: Lisboa; 49-70.

Silva N. 1990. Contribuição para o estudo antropológico da população de Povos do Ribatejo. Honours thesis, University of Coimbra, Portugal.

Sobral F. 1990. Secular changes in stature in Southern Portugal between 1930 and 1980 according to conscript data. Human Biology 62: 491-504.

Steckel R. 2004. New light on the "Dark Ages". The remarkably tall stature of Northern European men during the Medieval Era. Social Science History 28: 211-229. DOI: 10.1215/01455532-28-2-211

Steckel RH, Rose JC, Larsen CS, Walker PL. 2002. Skeletal health in the western hemisphere from 4000 B.C. to the present. Evolutionary Antbropology 11: 142-155. DOI: 10.1002/evan. 10030

Susanne C. 1984. Living conditions and secular trend. Studies in Human Ecology 6: 93-99.

Susanne C, Bodzsar E, Bielicki T, Hauspie B, Hulanicka B, Lepage Y, Rebato E, Vercauteren M. 2001. Changements séculaires de la croissance et du développement en Europe. Antropo 0: 71-90.

Tanner JM. 1982. The potential of auxological data for monitoring economic and social well-being. Social Science History 6: 571-581.

Tanner JM. 1989. Fetus into Man: Pbysical Growth from Conception to Maturity. Harvard University Press: Cambridge, MA.

Tanner JM. 1992. Growth as a measure of the nutritional and hygienic status of a population. Hormone Research 38 (Suppl. 1): 106-115.

Tavares P. 2003. Estudo paleoantropológico das sepulturas das alas norte e oeste do claustro do antigo convento dos Lóios de Arraiolos (Alto Alentejo). Honours thesis, University of Coimbra, Portugal.

Tavares P, Santos AL, Gonçalves A. 2003. Intervenção arqueológica e estudo antropológico da necrópole no castelo de Viana do Alentejo. Al-madam 12: 5465 .

Int. J. Osteoarchaeol. (2008) DOI: $10.1002 / \mathrm{oa}$ 
Tobias P. 1988. War and the negative secular trend of the South African blacks with observations on the relative sensitivity of cadaveric and non-cadaveric populations to secular effects. In Proceedings of the $5^{\circ}$ Congresso da Sociedade Europeia de Antropologia, volume 1, Mendes JC, Neto MC, Almeida MEC (eds). Sociedade Europeia de Antropologia: Lisboa 451-461.

Tortella G. 1994. Patterns of economic retardation and recovery in south-western Europe in the nineteenth and twentieth centuries. Economic History Review 47: 1-21.

Trotter M, Gleser G. 1952. Estimation of stature from long bones of American Whites and Negroes.
American Journal of Physical Antbropology 10: 463514.

Umbelino C. 1994. Contribuição para o estudo antropológico do espólio osteológico inumado na igreja de Santa Maria de Semide, nos sécs. XVI-XIX. Honours thesis, University of Coimbra, Portugal.

Waldron T. 1998. A note on the estimation of height from long-bone measurements. International Journal of Osteoarchaeology 8: 75-77. DOI: 10.1002/(SICI)10991212(199801/02)8:1<75::AID.-OA406>3.0.CO; $2-1$

Zilhão J. 1998. On logical and empirical aspects of the mesolithic-neolithic transition in the Iberian Peninsula. Current Antbropology 39: 690-698. 